\title{
INVESTMENT ACTIVITY OF INDUSTRIAL ENTERPRISES AND THEIR IMPORTANCE FOR THE DEVELOPMENT OF THE REGIONS IN THE COUNTRY (FOLLOWING THE EXAMPLE OF SPECIFIC REGIONS)
}

\author{
D. Blagoev*
}

Industrial Business Department, University of National and World Economy, Sofia, Bulgaria

\begin{abstract}
The purpose of this article is to identify the investment activity of industrial companies and the dynamics of foreign direct investment in a particular region of the country, to trace their dynamics in comparison with the general economic development of the region and to identify as a result the stimulating and/or limiting factors influencing on domestic and foreign investment. Methods such as literature review, observation, comparison, expert review, etc. are used to accomplish the set tasks and to achieve the set main goal. To achieve this goal, the following specific tasks are solved: (1) Defining theoretical and methodological aspects of investments; (2) A parallel between growth and development at both firm and regional levels has been drawn; (3) Identification of foreign investments in the region for a specified period of time; (4) Comparative analysis between the investment activity and the rate of change of the economic development of the region; Conclusions are presented about the main advantages and the respective limitations of the type of investments and differences in regional development
\end{abstract}

Keywords: Investments, Business organization, Growth, Economic development, Foreign Direct Investments (FDI)

JEL Classification: G11, G32, C61, L0

\section{INTRODUCTION}

One of the main functions performed by industrial enterprises is an investment and it is essential for ensuring the economic growth and development of the business entity. The investments of the enterprises (foreign and/or national) have a beneficial effect not only on the company that is performing them but also on the region in which it operates and is positioned the company. These benefits can have different dimensions (both direct and indirect). Investigating the investment activity of industrial companies and tracking their impact on the overall economic development of the regions (in the context of identifying

\footnotetext{
*Correspondence to: Assoc. Prof. Dr. Dimitar Blagoev, Industrial Business Department, University of National and World Economy, Sofia, Bulgaria,blagoev@unwe.bg, "Osmidekemvri" str., 1700 Studentski grad, Sofia, Bulgaria, telephone: +35928195512
}

stimulating or limiting factors in the dynamic environment of the contemporary environment) is an urgent problem.

\section{Theoretic-methodological aspects of investment}

The impact of investment and the investment process in the development of business organizations is undeniable. They have been the subject of interest from economic science for a long time. This is related to the constant interest of people in enhancing their wellbeing. In theory, there are many definitions of the nature of investments. According to the Bulgarian dictionary, investments are the use of financial resources in the form of long-term capital investments to increase the assets of the enterprise and obtain profit. Table 1 presents several concepts of investment by different authors. 
Table 1. Definitions of the concept of investment

\begin{tabular}{|l|l|}
\hline $\begin{array}{l}\text { Ivan } \\
\text { Georgiev }\end{array}$ & $\begin{array}{l}\text { Investments are defined as cash for the purchase of assets that are likely to provide } \\
\text { income, capital growth and other positive results over a long period of time (1). }\end{array}$ \\
\hline $\begin{array}{l}\text { Sharpe, } \\
\text { Alexander } \\
\text { and Bailey }\end{array}$ & $\begin{array}{l}\text { Investments are related to the refusal of a certain present value to obtain a future value } \\
(2) \text {. }\end{array}$ \\
\hline $\begin{array}{l}\text { Velcho } \\
\text { Stoyanov }\end{array}$ & $\begin{array}{l}\text { Investing can be presented as a process of investing cash (liquid) funds in all that } \\
\text { contributes to their future growth, i.e. to realize a certain income from the investment. } \\
\text { (3) }\end{array}$ \\
\hline $\begin{array}{l}\text { Dimitar } \\
\text { Nenkov }\end{array}$ & $\begin{array}{l}\text { Nenkov (4) determines that the investment can be defined as directing funds into } \\
\text { different types of assets in order to achieve a certain effect (including value) in the } \\
\text { future. According to the types of assets in which the funds are invested, investments } \\
\text { are financial and real. }\end{array}$ \\
\hline Peter Rose & $\begin{array}{l}\text { According to Peter Rose (5), the vast majority of funds set aside as savings go } \\
\text { through financial markets to support investments made by different business units or } \\
\text { by governments. Investments in this sense usually refer to the targeting of funds for } \\
\text { the purpose of acquiring the so-called 'capital goods', such as buildings and } \\
\text { equipment, as well as the purchase of stocks of raw materials or commodities for } \\
\text { disposal. }\end{array}$ \\
\hline $\begin{array}{l}\text { Angel } \\
\text { Marchev } \\
\text { Junior }\end{array}$ & $\begin{array}{l}\text { Investing is a process of knowingly, temporarily waiving the deployment of possessed } \\
\text { resources in pursuit of future repaid or future purposes and in taking certain risks (6). }\end{array}$ \\
\hline $\begin{array}{l}\text { Arthur } \\
\text { Sullivan, } \\
\text { and Steven } \\
\text { Sheffrin }\end{array}$ & $\begin{array}{l}\text { Sullivan and Sheffrin (7) Investments are the long-term use of cash or capital to } \\
\text { acquire financial instruments or other assets in order to achieve a profitable return in } \\
\text { the form of interest, other income or an increase in the value of the instrument. }\end{array}$ \\
\hline
\end{tabular}

Several specificities are highlighted in the definitions of investments. First, the investment requires spending before receiving any result from it. Contrary to the credit process, in which we initially receive financial or cash and in subsequent periods we recoup this value in a larger amount. When investing, we observe the reverse process. Initially, we spend cash or financial resources that in subsequent periods should bring positive cash flows to the business organization.

We can also determine the main purpose of the investment - the receipt of income or other positive results that exceeds the costs incurred. When we consider investments in the private sector, the objective pursued is always to exceed the costs incurred for them.

Investments also take into account the time factor. This is the difference in the period of realization of the investment and the receipt of its results. Usually, the investment is realized at the present moment or in a period close to it. The results of investments appear in a future period. In the case of investments in real assets, the period of cash flow generation depends on the nature of the project. In most cases, investments made generate cash flows over an extended period of time. They occur throughout the lifetime of the investment, and not only at the end.

The difference in time of the costs incurred and the income received from the investment makes it grounds to assume that the costs are secure and the revenues are uncertain. This means that the revenue and their amount are expected value based on any investor assumptions. The further away from these revenues, the greater the probability that the difference between the expected and actual revenues received will be large. This is one of the reasons why investments carry a certain risk.

Another aspect of investing is the change in liquidity. From one liquid resource (cash), another less liquid resource (machinery, buildings, shares, etc.) is acquired in order to obtain the initial liquid resource (money) again, but with an increased amount. The investor's loss of liquidity is also related to increasing the risk of the investment and, accordingly, to profitability. A rational investor would like to be compensated for the loss of liquidity.

The investment process is a sequence of stages that go through the realization of an investment project. A key point for this is a preliminary 
analysis. When investing in real assets in business organizations, we can distinguish between two different moments. Private investment process - these are the individual investment projects that are realized in the company and a common investment process - a multitude of individual (private) investment processes (projects).

This article focuses on the overall investment process. The emphasis is on comparing the overall investment process with economic growth and development.

When investing in real assets, the traditional practice of business organizations is to carry out only "profitable" projects. Under profitable, we understand investment projects that pass some financial efficiency criteria. Typically, this can be a net present value (NPV), an internal rate of return (IRR) or another selected benchmark.

\section{Growth and development at the company and regional level}

Whether an economy is developing well or not and is there growth - the universal measure of economic development around the world, gross domestic product (GDP) gives some answer to this question, but does not give a fully satisfactory answer. GDP is not an indicator of the overall well-being of the economy, although it is widely used as such. It (GDP) assesses the structure and activity of the economy, what it produces, how fast it grows, but does not take into account a number of factors important for sustainable development, such as the social and eco-environment in the country, inequalities, crime, etc. (8). Another similar indicator gross value added (GVA) shows production levels based on innovation or so-called high-value production.

These indicators take into account the effect of economic development in improving the overall standard of living in the economy of a country and/or region.

Ever since the beginning of the systematic economic analysis from the time of classical economists from William Petty to David Ricardo, the problem of economic growth - its sources, forms and consequences - has been high on the economists' agenda (9.)

At macro level, growth is explored as one of the phases of the economic cycle. This is evident in the economic theories of scholars of world renown such as P. Drucker, W. Rostow, J. Gulbright, M. Porter, R. Solou, M. Friedman, D. Robinson, et al. Modifications to growth theories, largely related to the available resource base, can be summarized in two main groups: Keynesian and neoclassical model of economic growth. With sufficient resource potential, economic growth is reflected in the continued increase in aggregate production (gross domestic product) created in the national economy, focusing on two important features: long-termity and mandatory growth. Most often, economic growth is treated as a sustained increase in the goods and services produced by a society, in particular an increase in real gross domestic product. As resources run out, attention shifts to their more economical, recyclable and even regenerative use.

In earlier research, growth was treated as a process of increasing the economic level that formed the general idea of economic development. It is later argued that economic development is a broader concept of economic growth, as it also includes social indicators in addition to economic indicators. A simpler perception is linking growth mainly to quantitative changes, and economic development, in addition to them, with qualitative changes. As a complex process, with many dimensions, economic growth goes beyond quantitative changes in resources, results achieved and the possibilities for converting resources into results. In addition, it is conditioned by a number of qualitative factors, which are generally more difficult to measure and evaluate. Often these are subjective factors related to entrepreneurial and management activity, innovation, etc. (10). In this direction, it can be said that the overall economic growth depends on the growth of the individual business units (companies), but it is not a purely mechanical sum of their growth, but a magnitude taking into account the synergistic effect of the individual growth of business organizations (companies).

At both national and individual company (business organisation) level, economic growth goes through the following stages (11):

Stage I: Resource-based growth (factor-driven growth);

Stage II: Efficiency-based growth;

Stage III: Innovation-based growth.

It is the third stage, the stage of growth based on innovation and generated by innovative 
companies, that has been of substantial interest in recent decades, given the depletability and limited availability of resources and to a certain extent the inability to generate growth from Stage I and Stage II.

In general, economic growth "depends on and is limited to the interaction between the results of the production process, the potential of production resources and the efficiency of their use. The interaction between them determines the type of growth and the efficiency or cost of that growth' (12). In terms of the possibility of its metricing and complex assessment over a given period, the following classification of growth and decline is appropriate (12) (Table 2)

Table 2. Opportunities for grouping economic growth/decline

\begin{tabular}{|c|c|}
\hline $\begin{array}{r}\text { Type of growth } \\
\end{array}$ & $\begin{aligned} \text { Type of decline } \\
\end{aligned}$ \\
\hline $\begin{array}{l}\text { I. Extensive growth } \\
\text { 1. Fully extensive growth due to: } \\
\text { (a) an unchanging level of the intensive factor; } \\
\text { (b) a decrease in the intensive factor. } \\
\text { 2. Mixed, with predominant extensive growth. }\end{array}$ & $\begin{array}{l}\text { I. Extensive decline } \\
\text { 1. A wholly extensive decline due to: } \\
\text { (a) an unchanging level of the intensive factor; } \\
\text { (b) an increase in the intensive factor. } \\
\text { 2. Mixed, with a predominantly extensive } \\
\text { decline. }\end{array}$ \\
\hline $\begin{array}{l}\text { II. Intensive growth } \\
\text { 1. Fully intensive growth due to: } \\
\text { (a) an unchanged level of the extensive factor; } \\
\text { (b) a decrease in the extensive factor. } \\
\text { 2. Mixed, with predominantly intense growth. }\end{array}$ & $\begin{array}{l}\text { II. Intense decline } \\
\text { 1. An entirely intense decline due to: } \\
\text { (a) an unchanging level of the extensive factor. } \\
\text { (b) increase in the intensive factor } \\
\text { 2. Mixed, with a predominantly intense decline. }\end{array}$ \\
\hline
\end{tabular}

Source: Nenov, T., Atanasov, B., Efficiency and Growth of industrial companies in modern conditions, Varna, 13-14, 2000.

Extensive growth is achieved by increasing production factors - capital and human resources. Therefore, it is defined as quantitative or resource-absorbing. Where the pace of change in production results coincides with those of the production factors, the level of cost-effectiveness shall not change. Intensive growth is the result of improved use of production factors through their qualitative improvement - implementation of progressive and innovative production technologies, improvement of labour organization and management, improvement of staff qualification and restructuring of production; therefore, defined as quality growth.

Intensive growth is growth based on innovation and innovation of companies. With higher rates of growth in final production performance than resources, the level of costeffectiveness improves. The transition from extensive to intensive development is objectively necessary due to the limited resource and the inability of both individual business organisations and national economies, in general, to function continuously in a declining cost-effectiveness. Whether extensive or intense, the downturn worsens the economic and financial situation, threatening the economic life of business organisations and the national economy (10).
It is important to note that there are similarities and differences between economic growth and economic development (13). The similarities refer to the fact that:

- growth and development are continuous processes that have stimulating effects in the economy;

- both processes include allocation and use of resources and efficiency gains;

- the ultimate objective of growth and development is to improve standard and quality of life;

- growth and development are the cause and effect of the general trend, influencing its rhythm and providing a shift from one level of economic development of society to another.

In contrast to economic developments at national level, economic growth can be assumed to be an increase in national income per capita and includes an analysis, especially in quantitative terms, of this process focusing on functional links between endogenous variables; more broadly, growth includes an increase in gross domestic product, gross national product and the national economy, hence national wealth, including production capacity, expressed both in absolute and relative terms, per capita, covering structural changes in the economy (14). 
Observed, as a per capita value, the individual indicators of macro-economic growth have an impact on it, and it (economic growth) may have the following values: positive, zero, negative. Positive economic growth is recorded when the average annual rate of change in macroeconomic indicators, in a positive direction, is higher than the average growth rates of the population. When the annual average growth rates of macroeconomic indicators, especially GDP, are equal to those of population growth, we can talk about zero economic growth. Negative economic growth occurs when the rates of population growth are higher than those of macroeconomic performance growth.

Investment activity of enterprises in the North-East region and south-east region (comparative analysis)
1. General characteristics of the regions.

The northeastern planning region covers the districts of Varna, Dobrich, Shumen and Targovishte. The southeastern planning region covers the districts of Burgas, Sliven, Yambol and Stara Zagora.

In the northeastern region is located one of the 6 largest cities, after Sofia, on the territory of the country and this is the city of Varna with populations (for 2017) of 335854 people. In the southeastern region are two of the 6 largest cities, after Sofia, on the territory of the country and these are the city of Burgas, with a population (for 2017) of 202694 and the city of Stara Zagora with a population (for 2017) of 136307 people. It is apparent that the two large cities in the South-East are comparable to one representative in the North-East region (15) (Table 3).

Table 3. Basic parameters of the comparison regions

\begin{tabular}{|l|l|l|l|l|l|}
\hline № & \multicolumn{1}{|c|}{ Region } & Population & $\begin{array}{c}\text { Area territory } \\
\text { (sq.km.) }\end{array}$ & $\begin{array}{c}\text { Population } \\
\text { density } \\
\text { (people/km2) }\end{array}$ & $\begin{array}{c}\text { Number of } \\
\text { municipalities }\end{array}$ \\
\hline 1. & North-East & 933705 & 14645 & 63,76 & 20 \\
\hline 2. & South-East & 1039549 & 19664 & 52,87 & 17 \\
\hline
\end{tabular}

Source: Socio-Economic Analysis of Regions in the Republic of Bulgaria, National Center for Territorial Development EAD, p. 1. 21, 2019.

The main parameters of the regions indicate their comparability with a slight advantage of the southeastern region. However, they can be used as a benchmark and give us an idea and a picture of the investments and their impact on the economic development of the regions.

\section{Foreign direct investment in the regions}

By their very nature, foreign direct investment (FDI) is financial resources invested for the purchase of tangible fixed assets, patents, trademarks, know-how, securities, creation of new fixed assets, reconstruction and expansion of existing tangible fixed assets, etc.

Foreign direct investment has always been a key criterion for the attractiveness of the economy in a region and/or country. Despite the view that more foreign direct investment is being made in some regions, the comparative analysis shows that, in relative terms, the rate of change over the years is comparable both between the two regions and compared to the overall national level of this type of investment
(Table 4). Over the ten-year period, the increase in foreign investment in both regions and the country as a whole was negligible. This is due to the loss of competitive advantages at a national and regional level. The focus is no longer on the low cost of labour, but on added value and innovation. This implies that in the coming years the regions, as well as the state, rethink its efforts to attract foreign investment and focus on creating and offering a favourable environment for innovation and production creation with high added value. This is one of the right paths for developing the regions and ensuring economic growth.

It can be said that in this case foreign direct investment is not a major driver (a major driving force) for the development of the two regions. The pace of their change is the same and none of them has a competitive advantage over the other in terms of attracting foreign investment. 
BLAGOEV D.

Table 4. Foreign Direct Investments

\begin{tabular}{|l|c|c|c|c|c|c|c|c|c|c|}
\hline & \multicolumn{10}{|c|}{ (in thousand euro) } \\
\hline & 2009 & 2010 & 2011 & 2012 & 2013 & 2014 & 2015 & 2016 & 2017 & 2018 \\
\hline $\begin{array}{l}\text { Country } \\
\text { level }\end{array}$ & 20441581 & 22114446 & 21644918 & 21950596 & 23339733 & 21581579 & 23163272 & 23508864 & 24475195 & 24919589 \\
\hline $\begin{array}{l}\text { North- } \\
\text { East } \\
\text { region }\end{array}$ & 2083919 & 2102923 & 2018734 & 2024996 & 2041479 & 2093916 & 2271913 & 2359757 & 2568878 & 2579480 \\
\hline $\begin{array}{l}\text { South- } \\
\text { East } \\
\text { region }\end{array}$ & 1857192 & 2728916 & 2947248 & 2866239 & 3385948 & 2057290 & 2897055 & 2847711 & 2983233 & 3203109 \\
\hline
\end{tabular}

Source: National Statistical Institute

3. Main areas of investment expenditure

Enterprises generate multiple investment costs each year. As indicated from a theoretical point of view, they relate to the private investment process (individual investment projects) and to the general investment process (all investments of the enterprises it makes over a certain period of time). Three of the main elements of the overall investment process have been traced from an empirical point of view. These are 'fixed asset costs', 'total investment costs' and 'innovation costs'. The cost of tangible fixed assets is the largest investment expense of companies. It is related to the specifics of the activity and the goals set by the management and the owners. In general, for enterprises (with the exception of so-called Start-up companies), ensuring growth is also related to the realization of specific investment intentions. In this context, the upward rate of change in investment by category and generally will be a fundamental prerequisite for enhancing the economic well-being of owners and regions.

Table 5. Main areas of investment costs in enterprises

\begin{tabular}{|c|c|c|c|c|c|c|c|c|c|c|}
\hline & & & & & & & & & \multicolumn{2}{|c|}{ (in thousand leva) } \\
\hline \multicolumn{11}{|c|}{ Expenditure on tangible fixed assets } \\
\hline & 2009 & 2010 & 2011 & 2012 & 2013 & 2014 & 2015 & 2016 & 2017 & 2018 \\
\hline $\begin{array}{l}\text { In general, } \\
\text { for the } \\
\text { country }\end{array}$ & 21274280 & 16218269 & 17913925 & 19091492 & 18089215 & 20123833 & 21191026 & 17671830 & 17628630 & 19249299 \\
\hline $\begin{array}{l}\text { North-East } \\
\text { Region }\end{array}$ & 2655227 & 1774046 & 1813295 & 1855328 & 2067581 & 1980140 & 2554872 & 1699996 & 2059160 & 2247188 \\
\hline $\begin{array}{l}\text { South East } \\
\text { Region }\end{array}$ & 2977022 & 2049325 & 2138085 & 2996234 & 2954486 & 3197989 & 2838777 & 2015270 & 2456648 & 2474456 \\
\hline \multicolumn{11}{|c|}{ Total investment costs in industrial enterprises } \\
\hline $\begin{array}{l}\text { In general, } \\
\text { for the } \\
\text { country }\end{array}$ & 6581361 & 5103531 & 5361442 & 7602323 & 5962956 & 6324499 & 5975881 & 5692090 & 5483668 & 5729893 \\
\hline $\begin{array}{l}\text { North- } \\
\text { East } \\
\text { Region } \\
\end{array}$ & 1178902 & 713432 & 511549 & 678945 & 763865 & 657926 & 1184235 & 508368 & 875141 & 726822 \\
\hline $\begin{array}{l}\text { South East } \\
\text { Region }\end{array}$ & 1529347 & 974161 & 1005303 & 1904090 & 1746753 & 1754856 & 1065147 & 799566 & 923440 & 983093 \\
\hline \multicolumn{11}{|c|}{ R\&D expenditure in enterprises } \\
\hline $\begin{array}{l}\text { In general, } \\
\text { for the } \\
\text { country }\end{array}$ & 108174 & 212107 & 228691 & 300305 & 318640 & 436957 & 623886 & 537932 & 534071 & 596083 \\
\hline $\begin{array}{l}\text { North- } \\
\text { East } \\
\text { Region } \\
\end{array}$ & & & 4933 & & & 12806 & 20461 & 33707 & 34239 & 30837 \\
\hline $\begin{array}{l}\text { South East } \\
\text { Region }\end{array}$ & 7490 & 10630 & 5866 & 8483 & 10183 & 20540 & 29222 & 26456 & 31338 & 33620 \\
\hline
\end{tabular}

Source: National Statistical Institute

The data show (Table 5) that for the period 2009-2018 investment expenditure have suffered a certain decline at regional and national level. At the starting and end point, there is almost no change in the most significant investment expenditure of companies, those for tangible fixed assets. A positive trend is that innovation expenditure 
( $R \& D$ expenditure) is reporting a strong pace of change in a positive direction. Given the time lag of the effect of innovation, it can be said that while maintaining and accelerating this trend, a positive influence on the economic development of regions and the country can also be expected.

\section{Comparative analysis of investment activity with the rate of change in the economic development of the region}

As indicated from a theoretical point of view, an indicator such as gross domestic product (GDP) may not be the perfect measure of the economic growth and development of regions and countries, but it has been accepted as universal. Together with an indicator such as gross value added (GVA) gives us a good enough picture of the trends in the development of the regions. Data for the regions surveyed show that GDP and GVA have an upward rate of change over the period considered. It is analogous to the national rate of change in GDP and GVA with a slight lag. Again, it is observed that the southeastern region is better developed economically. However, the rate of change over the last 10 years of economic development of both regions is happening in the same way (Table 6). The gap in the GVA indicator is significantly more pronounced than in the GDP indicator, where the two regions move in small margins of divergence. This fact shows us that in the southeastern region it produces production with higher added value, but in a smaller amount. In the northeast region, things go the other way. There, the production has a slightly lower added value, but a larger quantity is produced. This to a certain extent compensates and eliminates the backlog of GDP generated. The comparative analysis of investments for the period (foreign direct investment, fixed asset investments, $R \& D$ investments) and economic growth show us that although investments in the regions do not increase, indicators such as GDP and GVA have an upward growth rate. This upward growth rate is due to a significant increase in one of the investment costs, that of $R \& D$ and an increase in production with higher added value. This is happening in both regions, but at a much faster rate in the southeastern region than in the northeastern region.

Overall, in the last 10 years, there have been no major positive changes in the main observed indicators at a company and national level. Maintaining the condition for such a long period shows that the business environment does not get worse, but has not improved to attract more investment and this will lead to accelerated economic growth for the future.

Table 6. Main macroeconomic indicators

\begin{tabular}{|l|c|c|c|c|c|c|c|c|c|c|}
\hline \multicolumn{10}{|c|}{ Gross value added (GVA) } \\
\hline & 2009 & 2010 & 2011 & 2012 & 2013 & 2014 & 2015 & 2016 & 2017 & 2018 \\
\hline $\begin{array}{l}\text { In general, for } \\
\text { the country }\end{array}$ & 19371 & 17326 & 20239 & 20366 & 19022 & 19657 & 21158 & 23024 & 24821 & 24522 \\
\hline $\begin{array}{l}\text { North-East } \\
\text { Region }\end{array}$ & 1888 & 1780 & 2183 & 2237 & 2125 & 2281 & 2371 & 2504 & 2633 & 2735 \\
\hline $\begin{array}{l}\text { South East } \\
\text { Region }\end{array}$ & 3250 & 3114 & 3377 & 3634 & 3546 & 3937 & 3865 & 4921 & 5214 & 4714 \\
\hline & 73147 & 74407 & 80682 & 82209 & 81919 & 83857 & 89333 & 95092 & 102308 & 109695 \\
\hline $\begin{array}{l}\text { In general, for } \\
\text { the country }\end{array}$ & 7866 & 7857 & 8630 & 8947 & 8906 & 9311 & 9705 & 10094 & 10793 & 11647 \\
\hline $\begin{array}{l}\text { North-East } \\
\text { Region }\end{array}$ & 8974 & 9019 & 9607 & 10062 & 10135 & 10623 & 10885 & 12335 & 13197 & 13245 \\
\hline $\begin{array}{l}\text { South East } \\
\text { Region }\end{array}$
\end{tabular}

Source: National Statistical Institute

\section{CONCLUSIONS}

Based on the analysis of the investment activity of companies in the south-eastern and northeastern regions and the comparative analysis with their general economic 
development of the country, the following summaries and conclusions can be done:

- The industry in the southeastern region produces production with higher GVA than the industry in the northeastern region;

- Foreign direct investment does not prove to be an essential factor for the economic prosperity of the regions;

- In many cases, the reduction in foreign direct investment is offset by an increase in investment by local economic business organizations (and vice versa);

- Investment activity does not prove to be the main determinant for generating higher GDP and GVA;

- The same rate of change in GDP and at the same time the distance (gap) in the GVA charts shows that the backlog in production with higher added value is offset (in part) by producing a higher quantity of output with lower added value.

\section{REFERENCES}

1. Georgiev, Iv., Fundamentals of Investment, Publishing Complex UNWE, Sofia, 2013.

2. Sharpe,W.F., Alexander, G.J., Bailey, J.V., Investments (Fifth edition); Prentice Hall International Inc., 1995

3. Stoyanov, V., Finance of the enterprise (company) - Part II. S., 1995.

4. Nenkov, D., Valuation of investments in real assets., University Publishing House "Stopanstvo", Sofia, 2005.

5. Rose, P.C., Money and Capital Markets, R.D. Irwin, Inc., 1994

6. Marchev Jr., Ang., Selection of models for management of investment portfolios, Publishing Complex UNWE, Sofia, 2012.

7. Sullivan, A., Sheffrin, St., Economics:Principles in action.Upper Saddle River, New Jersey, 2003.
8. Ignatova, L., Measure me, if you can, Capital newspaper, year XXVI, 21.XII.2018-3.I.2019, ed. "Economedia" JSC, p. 1. 44, 2019.

9. Heinz D., Salvadori, Kurz \& Neri, Theories of Economic Growth - Old and New, 2016,online on: https://www.researchgate.net/publication/2 52313772_Theories_of_Economic_Growth --_Old_and_New

10.Mitov, K., Tsvetkova, M., Koleva, R., Doncheva, L. et al., Efficiency and economic growth of industrial business in modern conditions, Scientific priority: Crises and Sustainable Development of SA D.A. Tsenov-Svishtov, online on: http://eprints.ugd.edu.mk/10834/1/Proekt\% 20.pdf

11.Annual report of the Applied Research and Communications Foundati onhttp://www.arcfund.net/fileSrc.php?id=2 0463.

12.Nenov, T., Atanasov, B., Efficiency and growth of industrial companies in modern conditions. Varna, 39., 2000.

13. Haller A., Exporturile - factor de dezvoltare şi creştere economică, Performantica Publishing House, Iasi, 2008.

14. Haller A., Concepts of Economic Growth and Development. Challenges of Crisis and of Knowledge, Journal Economy Transdisciplinarity Cognition, Vol. 15, Issue 1, pp. 66-71, 2012.

15.*** Socio-economic analysis of the regions in the Republic of Bulgaria, National Center for Territorial Development EAD, p. 1. 36, 2019. 